\title{
Recenzja
}

\section{Karolina Karpus, Systemy podatków lokalnych w wybranych państwach europejskich, Wydawnictwo Adam Marszałek, Toruń 2003, ss. 163}

Recenzowana praca nie jest pozycją nową na rynku, niemniej jednak wartą polecenia $z$ uwagi na jej walor poznawczy. To niezbyt wielkie objętościowo opracowanie składa się z czterech rozdziałów opatrzonych wstępem. Układ książki jest logiczny. Rozpoczyna się rozważaniami natury teoretycznej. Pierwszy rozdział dotyczy kwestii podstawowych w zakresie systemu podatków lokalnych. Następnie omawiane są kompetencje jednostek samorządu terytorialnego w obszarze podatków lokalnych. Część dogmatyczna pomieszczona została w jednym, szerokim objętościowo, rozdziale. Zaprezentowane w nim zostały regulacje dotyczące podatków lokalnych w wybranych państwach europejskich. W ostatnim rozdziale poruszono właściwie jedynie wybrane problemy funkcjonowania systemu podatków lokalnych. Pracę zamyka skromne podsumowanie.

Książka opatrzona jest tytułem Systemy podatków lokalnych $w$ wybranych państwach europejskich. W treści opracowania Autorka posługuje się jednak pojęciem „systemu”. Tytuł natomiast sugerować może wielość występujących rozwiązań natury systemowej. Czytelnik zaś jedynie domyśla się na podstawie lektury całości analizy, że możliwe są rozmaite rozwiązania konstrukcyjne w dziedzinie podatków lokalnych w poszczególnych państwach. Autorka wskazuje bowiem np. typy podatków lokalnych, omawia rozwiązania normatywne na podstawie regulacji krajowych oraz schematów teoretycznych (np. s. 34, 40-41). Wydaje się więc osiągalne uporządkowanie i zasugerowanie choćby potencjalnych odrębnych konstrukcji prawnych w zakresie funkcjonowania podatków lokalnych w państwach. Nie odnajdujemy jednak takich zabiegów w treści wywodu K. Karpus.

Pewne zastrzeżenia, właśnie we wskazanym kontekście, mogą pojawiać się przy ocenie doboru państw do analizy. Autorka wprawdzie wskazuje we 
Wstępie przesłanki ich wyboru i przekonująco uzasadnia wyłonienie Wielkiej Brytanii oraz Francji, jednak w odniesieniu do pozostałych państw (Węgry, Czechy i Polska) brakuje, jak się wydaje, należytej argumentacji. Różnice między tymi systemami, budowanymi w państwach przechodzących reformę samorządową i aspirujących do UE, nie zostały wskazane. Uzasadniać one natomiast powinny dobór państw zakwalifikowanych do analizy odrębnych systemów podatków lokalnych. Poza tym w systemie polskim i czeskim, nawet już na podstawie pobieżnej lektury, zauważalne są pewne podobieństwa konstrukcyjne. Aspekt ten nie został jednak należycie wykazany w książce.

Opracowanie stanowi niewątpliwie bogate źródło informacji na temat samych podatków lokalnych, ale także innych dochodów budżetów lokalnych (np. systemu dotowania czy udziału w podatkach państwowych). Rozważania prowadzone są na poziomie regulacji ustawowych państw objętych analizą. Poruszane są przy tym kwestie nie tylko kompetencji w zakresie ustalania wysokości dochodów, ale także administrowania podatkami lokalnymi. Ujawnia się tu znaczący aspekt poznawczy pracy. Należy ona niewątpliwie do grupy opracowań finansowoprawnych i z tego punktu widzenia prezentowane są poszczególne instytucje normatywne.

Interesującym jednak uzupełnieniem poruszanych kwestii byłaby także analiza konstytucyjnoprawna. Być może należałoby w tym celu wyróżnić polski system podatków lokalnych w odrębnym rozdziale i szerzej go opracować. Autorka wskazuje co prawda incydentalnie niektóre przepisy konstytucyjne (art. 167 Konstytucji RP w zakresie dochodów samorządowych oraz art. 217 Konstytucji RP w zakresie konstrukcji normatywnej stanu podatkowoprawnego), niemniej jednak kluczowe kwestie pozostają poza głównym nurtem jej rozważań. Pominięty został bowiem kluczowy przepis konstytucyjny - art. 168, przesadzający o tym, że jednostki samorządu terytorialnego mają prawo ustalania wysokości podatków i opłat lokalnych w zakresie określonym w ustawie. Autorka wprawdzie podkreśla konieczność powierzenia jednostkom samorządowym pewnego zakresu swobody decyzyjnej, nie wiąże go jednak z art. 168 polskiej ustawy zasadniczej. Przepis ten jest natomiast podstawą do budowania koncepcji władztwa daninowego jako kategorii przysługującej państwu z możliwością jego udzielenia 
wspólnotom lokalnym¹ ${ }^{1}$ W tym kontekście nie do końca jasny i przekonujący może być pogląd o skłonności ustawodawcy do ograniczania władztwa podatkowego samorządów lokalnych (s. 44-45). Ustawodawca nie ogranicza bowiem „władztwa” będącego przymiotem państwa, a jedynie udziela pewnych kompetencji z przysługującej mu w dalszym ciągu „wiązki” suwerennych uprawnień. Uprawnienia jednostek samorządu terytorialnego uzasadnione są oczywiście konstytucyjnym statusem wspólnot mieszkańców danego obszaru oraz uczestnictwem w sprawowaniu władzy publicznej na zasadzie jej decentralizacji (art. 15 i 16 Konstytucji RP). Regułą udzielania władztwa powinna być pomocniczość, nie zaś kategoryczna delimitacja kompetencji państwowych i samorządowych.

W opracowaniu jeszcze jeden aspekt wydaje się istotny z konstytucyjnoprawnego punktu widzenia. Ustawa zasadnicza nie wymaga bowiem dla uchwał organów samorządowych szczegółowego upoważnienia, jak w odniesieniu do rozporządzeń wykonawczych. Akty prawa miejscowego wydawane są przecież na podstawie i w granicach upoważnień zawartych w ustawie. Tymczasem K. Karpus zdaje się utożsamiać te dwa przypadki aktów podustawowych (s. 48). Logika natomiast odrębnego traktowania tych dwóch kategorii normatywnych związana jest ze szczególnym charakterem aktów prawa miejscowego. Powinny być one przecież dostosowane między innymi do odmiennych warunków lokalnych. Szczegółowe upoważnienie mogłoby powodować wysoką jednolitość rozwiązań przyjmowanych w całym kraju, a to wywołuje z kolei dysonans z ideą podziału terytorialnego państwa, uwzględniającego więzi społeczne czy gospodarcze występujące odrębnie w poszczególnych jednostkach samorządowych.

Pewne wątpliwości pojawiają się także w kwestii terminologicznej, rzutującej na zakres analizy objętej pracą. Autorka odnosi swoje rozważania wyraźnie do kategorii podatków. Są one niewątpliwie jednym z rodzajów danin publicznych wyróżnianych w teorii finansów publicznych, ale również w doktrynie prawa konstytucyjnego. Obok podatków wyróżnia się także opłaty i dopłaty oraz cła jako odrębne konstrukcyjnie daniny publiczne. Poza nimi występuje także bardzo szeroka gama rozmaitych świadczeń o mieszanych cechach. Autorka zauważa tę wielość form w części szczegó-

Por. szerzej na ten temat: A. Bień-Kacała, Zasada władztwa daninowego w Konstytucji $R P z 1997$ r., Toruń 2005, passim oraz wskazane tam wcześniejsze opracowania na ten temat, powoływane także przez K. Karpus. 
łowej, poświęconej rozwiązaniom polskim i czeskim. Pojawia się tam, obok podatków, kategoria opłat. Dobrze byłoby zatem nieco rozszerzyć pole badawcze na inne daniny publiczne. Tym bardziej że w klasyfikowaniu danin ich nazwa nie odgrywa pierwszorzędnej roli. Szczegółowa analiza daninowych wpływów do budżetów samorządowych mogłaby pomóc w ustaleniu rzeczywistego zbioru świadczeń kwalifikowanych jako podatki lokalne. Można posłużyć się tu przypuszczeniem, że nie zamknąłby się on w granicach ustawy o podatkach i opłatach lokalnych. Poza tym warto w zakresie definiowania kategorii podatków lokalnych zwrócić uwagę jeszcze na kwestię lokowania całości wpływów do budżetów jednostek samorządowych obok lokalnego ich znaczenia.

Praca, poza walorem poznawczym, stanowi cenne źródło uwag z zakresu polityki podatkowej i kształtowania systemu podatkowego od strony materialnej. Autorka słusznie wskazuje, że celem systemu podatków lokalnych jest głównie zapewnienie samorządom samodzielności finansowej niezbędnej do wypełnienia przypisanych im zadań. Podkreśla także konieczność powiązania między podatnikami podatków lokalnych a usługami publicznymi dostarczanymi przez samorządy dla tych podatników. Istotna jest także reguła równomierności występowania źródeł podatkowych w całym kraju, konieczna do zastosowania przy konstruowaniu systemu podatków lokalnych. Niweluje ona nieco w zakresie wpływów różnice społeczne i gospodarcze będące podstawą wytyczania granic wspólnot samorządowych. Ostrożnie jednak podchodziłabym do tezy o wybieraniu przez przedstawicieli samorządów lokalnych niższych podatków lokalnych z uwagi na prowadzoną politykę wyborczą (s. 23-24). Posługując się publicystycznym rozumieniem deficytu finansów publicznych, w tym lokalnych, skłania decydentów do oscylowania raczej przy górnej granicy dopuszczalnych stawek.

Autorka porusza także bardzo istotna kwestię „różnic w bogactwie” jednostek samorządowych. Wpływa to oczywiście na stopień zaspokajania potrzeb ich mieszkańców. Sytuacja ta powinna, słusznym zdaniem K. Karpus, zostać uwzględniona przy konstruowaniu systemu dochodów jednostek samorządu terytorialnego, w tym systemu podatkowego. Samorządy lokalne powinien cechować wysoki stopień samodzielności finansowej, ocenianej na podstawie poziomu pokrycia finansowania zadań publicznych z dochodów własnych bezzwrotnych. Jest to trudna dla samorządów sytuacja w związku z identyfikacją zjawiska „spychania” obowiązku finansowania szero- 
kich zadań na samorządy i przekazywaniem niewystarczających środków na ich zaspokajanie (s. 151). Sytuacja ta ujawnia się choćby w odniesieniu do oświaty, zbyt często ewidentnie niedofinansowanej. Stan ten obrazuje jednocześnie wagę lokalnej gospodarki finansowo-budżetowej w wywiązywaniu się z konstytucyjnych zadań przez państwo, np. w zakresie realizacji prawa do nauki, a nie tylko nadzoru nad wykonywaniem obowiązku szkolnego.

W podsumowaniu recenzji pragnę jeszcze raz podkreślić jednak przydatność recenzowanej książki dla czytelnika zainteresowanego materią finansową, samorządową, ale także konstytucyjną. Umiejętność identyfikowania mogących pojawiać się w praktyce problemów dobrze służyć będzie kształtowaniu polityki finansów samorządowych. Pomoże przy tym w ustalaniu konkretnych wzorców normatywnych rozwiązań. Odpowiednie ukształtowanie systemu podatkowego służy przecież umacnianiu wspólnoty państwowej i samorządowej. Obowiązek ponoszenia danin publicznych skorelowany jest przecież z możliwością zaspokajania przez wspólnotę potrzeb jednostki, ale i potrzeb wspólnoty, w której ta jednostka funkcjonuje.

Agnieszka Bień-Kacała (Uniwersytet Mikołaja Kopernika w Toruniu) 